\title{
OXIDATIVE STRESS PARAMETERS IN POSTTRAUMATIC STRESS DISORDER RISK GROUP PATIENTS
}

\author{
Vladimirs Voicehovskis*, Gunta Ancāne*, Jūlija Voicehovska**, \\ Grigorijs Orḷikovs**, Jurijs Karpovs**, Igors Ivanovs***, Andrejs Šḳesters****,

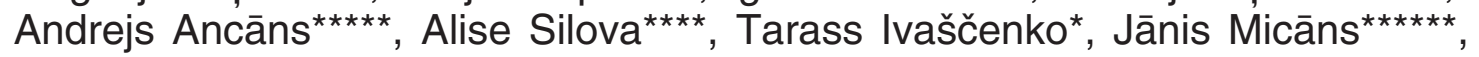 \\ Normunds Vaivads ${ }^{\star \star \star \star \star \star \star}$, and Larisa Umnova** \\ * Department of Psychosomatic Medicine and Psychotherapy, Rīga Stradiṇš University, Kapseḷu iela 23, Rīga, LV-1046, LATVIA; \\ vladimirs.voicehovskis@rsu.Iv \\ ** Internal Diseases Department, Rīga Stradiṇš University, Pilsoṇu iela 13, Rīga, LV-1002, LATVIA \\ *** Rīga 1st Hospital, Bruṇinieku iela 5, Rīga, 1001, LATVIA \\ **** Biochemical Laboratory, Rīga Stradinš University, Dzirciema iela 16, Rīga, LV-1007, LATVIA

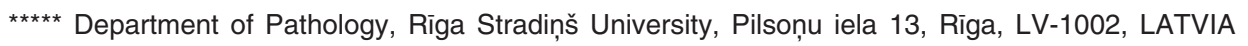 \\ ***** Joint Staff Medical Department, National Armed Forces, LATVIA \\ $\star \star \star \star \star \star \star \star 3 d$ RLC Medical Care Centre, National Armed Forces, LATVIA
}

Communicated by Rafails Rozentāls

Increased excitotoxity in response to stressors leads to oxidative stress (OS) due to accumulation of excess reactive oxygen/nitrogen species. Neuronal membrane phospholipids are especially susceptible to oxidative damage, which alters signal transduction mechanisms. The Contingent of International Operations $(\mathrm{ClO})$ has been subjected to various extreme stressors that could cause Posttraumatic Stress Disorder (PTSD). Former studies suggest that heterogeneity due to gender, race, age, nutritional condition and variable deployment factors and stressors produce challenges in studying these processes. The research aim was to assess OS levels in the PTSD risk group in ClO. In a prospective study, 143 participants who were Latvian CIO, regular personnel, males, Europeans, average age of 27.4, with the same tasks during the mission, were examined two months before and immediately after a six-month Peace Support Mission (PSM) in Afghanistan. $P C L-M$ questionnaire, valid Latvian language "Military" version was used for PTSD evaluation. Glutathione peroxidase (GPX), superoxide dismutase (SOD) and lipid peroxidation intensity and malondialdehyde (MDA) as OS indicators in blood were determined. Data were processed using SPSS 20.0. The MDA baseline was $2.5582 \mu M$, which after PSM increased by $24.36 \%(3.1815$ $\mu M)$. The GPX baseline was $8061.98 \mathrm{U} / \mathrm{L}$, which after PSM decreased by 9.35\% (7308.31 U/L). The SOD baseline was $1449.20 \mathrm{U} / \mathrm{gHB}$, which after PSM increased by $2.89 \%$ (1491.03 U/gHB). The PTSD symptom severity (total PCL-M score) baseline was 22.90 points, which after PSM increased by $14.45 \%$ (26.21 points). The PTSD Prevalence rate (PR) baseline was 0.0357 , which after PSM increased by $147.06 \%$ (0.0882). We conclude that there is positive correlation between increase of OS, PTSD symptoms severity level, and PTSD PR in a group of patients with risk of PTSD - CIO. PTSD PR depends on MDA intensity and OS severity. OS and increased free radical level beyond excitotoxity, is a possible causal factor for clinical manifestation of PTSD.

Key words: Posttraumatic stress disorder, oxidative stress.

\section{INTRODUCTION}

The Contingent of the International Operations appears to be subject to various extreme factor actions, which can cause Posttraumatic Stress Disorder (PTSD). PTSD is an anxiety disorder that can develop after exposure to one or more traumatic events, threatening or causing great physical harm; it is a complex of symptoms experienced by survi- vors of traumatic stress (Satcher, 2000). General PTSD symptoms occur in complex psycho-physiological hypertrophic responses: intrusive experiences of a traumatic event, illusions, hallucinations, persistent avoidance of stimuli associated with trauma, and general emotional numbness, which are present for a period of at least one month. Clinical diagnosis of PTSD, according to the Diagnostic and Statistical Manual of mental disorders (DSM-IV-TR), is per- 
formed by means of a clinical PTSD checklist PCL-M (military version). PCL-M includes 17 items. It is recommended for use as an objective diagnostic tool for examination of patients with PTSD and PTSD risk group patients (Anonymous, 2000; Weathers et al., 2001; Watson et al., 2005; Pynoos et al., 2009; McDonald and Calhoun, 2010).

According to available literature data, the PTSD level before Peace Support Missions has been reported as high as 2.4-9.3\% in the American Contingent of the International Operations (Hoge et al., 2004; Riddle et al., 2007) and $2.4 \%$ in the British Contingent of the International Operations (Iversen et al., 2009). PTSD level after Peace Support Mission is reported as $11.2 \%$ in the American Contingent of the International Operations (Hoge et al., 2004) and 4.0-9.5\% in the British Contingent of the International Operations (Hotopf et al., 2006; Iversen et al., 2009). Pathophysiology and pathogenesis of PTSD is associated with excitotoxity. Excitotoxity is the pathological process by which neurons are damaged due to hyperactivations of the excitatory neurotransmitter glutamate ( $\mathrm{Li}$ et al., 2001, Jourdain et al., 2007). Excitotoxity-activated microglia cells appear to become probable sources of chronic oxidative processes leading to oxidative stress (Anwyl, 1991). Neuronal membrane phospholipids are especially vulnerable to damage; the injury leads to the receptor-mediated signal transduction and, furthermore, information processing disorders. Studies on the effects of hyperoxidation, oxidative and carbonyl stresses on cerebral suppression and its relation to brain degeneration with respect of neuronal functions are of great interest and importance. Indeed there are difficulties in rating and interpreting of available literature data, as the studies are inhomogeneous in gender, race, age, nutritional and deployment factors - reservists or regular personnel, and different stressful military experiences in various Peace Support Missions.

Oxidative stress intensity was assessed considering the malondialdehyde (MDA) plasma level. Unsaturated carbonyl MDA is one of the most frequently used direct indicators of lipid peroxidation. MDA measurement appears to be a suitable quantification method of the end-products of lipid peroxidation. The production of MDA is used as a biomarker to measure the level of OS in an organism and is often used in oxidative stress studies (Moore and Roberts, 1998; Del Rio et al., 2005; Nie et al., 2007). MDA is a naturally occurring metabolic product of polyunsaturated fat degradation (lipid peroxidation), and has been reported to be mutagenic and carcinogenic. Free radical damage to lipids results in MDA reacting with DNA to form adducts to deoxyguanosine and deoxyadenosine and releasing an intermediate product of formaldehyde (Nie et al., 2007). Formaldehyde at low concentrations induces protein misfolding causing a high cytotoxic aggregation. As a metabolic product, MDA might weaken cerebral function during oxidative stress through breaking the homeostasis between excitatory and inhibitory neurons. Being less active than other free radical, MDA has a rather longer half-life and, thereby, can diffuse from the generation places to other sites, bringing further oxidative stress. Cells are equipped with enzymatic and nonenzymatic antioxidant systems to eliminate ROS/RNS and maintain redox homeostasis. A major class of enzymatic antioxidants, which catalyze the dismutation of superoxide into oxygen and hydrogen peroxide, is known as superoxide dismutase (SOD). Multiple isoforms of SOD exist in different cellular compartments. SOD1 (CuZnSOD) is the major superoxide scavenger found in the cytoplasm, mitochondrial intermembrane space, nucleus, and lysosomes, whereas SOD2 (MnSOD) and SOD3 are found in the mitochondria and extracellular matrix, respectively. Indeed, they impart an important antioxidant defence system and their activity increases upon oxidative stress. Some SOD isoforms resulting from oxidative stress have been linked with human diseases. Thus, mutations in the CuZnSOD can result in familial amyotrophic lateral sclerosis (Milani et al., 2011). Further conversion of hydrogen peroxide occurs through the action of catalase, a heme-based enzyme that is normally localised in the peroxisome. Hydrogen peroxide also can be converted to oxygen through coupled reactions with the conversion of reduced glutathione to oxidized glutathione, catalysed by glutathione peroxidase $(\mathrm{GPx})$. The main biological role of GPx is to protect the organism from oxidative damage. The biochemical function of GPx is to reduce lipid hydroperoxides to alcohols as well as to reduce free hydrogen peroxide to water (Miyamoto et al., 2003). GPx scavenges extremely active hydroxyl radicals without formatting toxic adverse products. GPx is present in a high concentration in the cells and plays a crucial role in ensuring them in a reduced state. The GPx role as antioxidant is particularly important for brain, as it is very sensitive to presence of free radicals. Insufficient GPx amount and/or activity can complicate oxidative stress. Five isoforms of selenium (Se)-dependent GPx are found in humans. Furthermore, enzymes such as glutathione S-transferases are known to have Se-independent peroxidase activity. Nonenzymatic antioxidants (thioredoxin, glutaredoxins, peroxiredoxins), recognised to execute thioldisulfide exchange reactions, also play a major role in maintaining cellular redox balance (Trachootham et al., 2008).

Our research aim was to assess oxidative stress levels PTSD and their correlation in the Contingent of the International Operations.

\section{MATERIALS AND METHODS}

The prospective study was conducted in the Department of Psychosomatic Medicine and Psychotherapy, Rīga Stradņš University (Riga, Latvia) in close cooperation with the Biochemical Laboratory (Rīga, Latvia) and Department of Internal Diseases (Rīga, Latvia) of Rīga Stradiņš University, and Medical Care Centre of the National Armed Forces (Rìga, Latvia). The protocol of study, the protocol of agreement, and the protocol of participation corresponded to the Helsinki declaration on principles of humanity in medicine. The study design was approved by the Ethics Committee of Rīga Stradiņš University, protocol No. E-9(2) of 17.12.2009. For our research we used a participant group with the highest possible level of homogeneity to avoid dif- 
ficulties in rating and interpreting of results. In total there were 143 male European participants, average age 27.4, regular military personnel, participants of the Latvian Contingent of the International Operations. Examination was performed before and after the same Peace Support Mission in Afghanistan (six months), with the same tasks during the mission. Clinical examination and laboratory parameters assessment were taken twice: two months before the mission (BL) and immediately after the mission (PL).

Clinical examination was made according to the diagnostic pattern DSM-IV-TR (Anonymous, 2000). The following diagnostic criteria were assessed:

Criterion A: Stressor. The person has been exposed to a traumatic event in which both of the following have been present:

1. The person has experienced, witnessed, or been confronted with an event or events that involve actual or threatened death or serious injury, or a threat to the physical integrity of oneself or others;

2. The person's response involved intense fear, helplessness, or horror.

Criterion B: Intrusive recollection. The traumatic event is persistently re-experienced in at least one of the following ways:

1. Recurrent and intrusive distressing recollections of the event, including images, thoughts, or perceptions;

2. Recurrent distressing dreams of the event;

3. Acting or feeling as if the traumatic event were recurring (includes a sense of reliving the experience, illusions, hallucinations, and dissociative flashback episodes, including those that occur upon awakening or when intoxicated);

4. Intense psychological distress at exposure to internal or external cues that symbolise or resemble an aspect of the traumatic event;

5. Physiologic reactivity upon exposure to internal or external cues that symbolise or resemble an aspect of the traumatic event.

Criterion C: Avoidant/numbing. Persistent avoidance of stimuli associated with the trauma and numbing of general responsiveness (not present before the trauma), as indicated by at least three of the following:

1. Efforts to avoid thoughts, feelings, or conversations associated with the trauma;

2. Efforts to avoid activities, places, or people that arouse recollections of the trauma;

3. Inability to recall an important aspect of the trauma;

4. Markedly diminished interest or participation in significant activities;
5. Feeling of detachment or estrangement from others;

6. Restricted range of affect (e.g., unable to have loving feelings);

7. Sense of foreshortened future (e.g., does not expect to have a career, marriage, children, or a normal life span).

Criterion D: Hyper-arousal. Persistent symptoms of increasing arousal (not present before the trauma), indicated by at least two of the following:

1. Difficulty falling or staying asleep;

2. Irritability or outbursts of anger;

3. Difficulty concentrating;

4. Hyper-vigilance;

\section{Exaggerated startle response;}

Criterion E: Duration. Duration of the disturbance (symptoms in $\mathrm{B}, \mathrm{C}$, and $\mathrm{D}$ ) is more than one month.

Criterion F: Functional significance. The disturbance causes clinically significant distress or impairment in social, occupational, or other important areas of functioning.

PCL checklist was worked out at PTSD National Centre, USA in 1993. The PCL has a variety of purposes, including screening individuals for PTSD, diagnosing PTSD, monitoring symptom change during and after treatment. There are three versions of the PCL: PCL-C (civilian), PCL-M (military) and PCL-S (specific). PCL-M asks about symptoms in response to "stressful military experiences" and is used for active service members and veterans (Weathers et al., 2001; Watson et al., 2005; McDonald and Calhoun, 2010). The PTSD Checklist (PCL) is a 17-item self-report measure of the 17 DSM-IV symptoms of PTSD. Respondents are asked about certain troubles during the last month; the answers are evaluated by a 5-point scale. The valid Latvian language PCL-M version was used for objective PTSD evaluation (Voicehovskis et al., 2011). PTSD risk group Incidence rate (IR) was also assessed.

Laboratory assessment of oxidative stress parameters in blood included: intensity of lipid peroxidation assessed by malondialdehyde (MDA) concentration and activity of antioxidant enzymes: glutathione peroxidase (GPx) and superoxide dismutase (SOD). Blood samples were taken from all individuals in morning at 8.00 (before meal). Venous blood was collected into a vacutainer (Venoject II BD) containing lithium/heparin as an anticoagulant.

Activity of glutathione peroxidase 3 (GPx), Enzyme Commission number (EC) 1.11.1.9, was determined in heparinised whole blood by the method of Paglia and Valentine (Paglia and Valentine, 1967) using commercial tests manufactured by Randox Laboratories (UK, Antrium) in a RX Daytona analyser. GPx catalyses the oxidation of glutathione (GSH) by cumene hydroperoxide. In the presence of glutathione reductase and nicotinamide adenine dinucleo- 
THE MAIN RESULTS BEFORE (BL) AND AFTER (PL) THE PEACE SUPPORT MISSION (PSM) (one-sample Kolmogorov-Smirnov test)

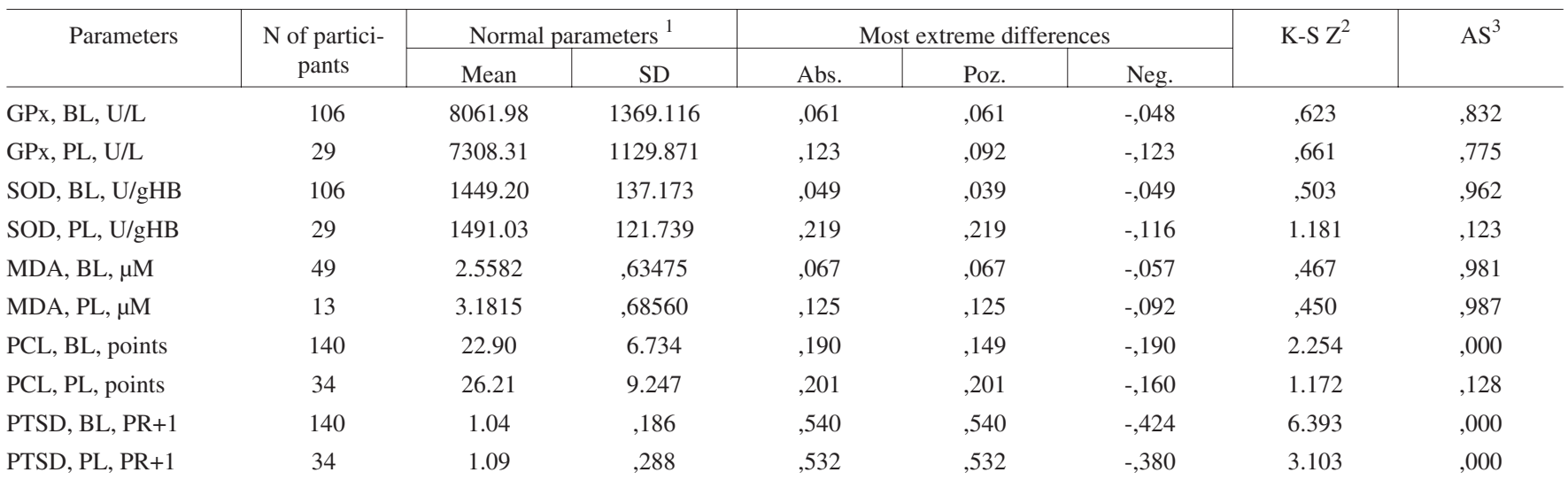

${ }^{1}$ Test distribution is normal; calculated from data; ${ }^{2}$ Kolmogorov-Smirnov Z; ${ }^{3}$ asymptotic significance; SD, standard deviation; GPx, glutathione peroxidase; SOD, superoxide dismutase; MDA, malondialdehyde; PTSD, Posttraumatic Stress Disorder; PCL-M, PTSD Checklist - Military Version

tide phosphate (NADPH) the oxidised glutathione (GSSG) is immediately converted to the reduced form with a concomitant oxidation of NADPH to the oxidised NADP ${ }^{+}$. The decrease in absorbance at $340 \mathrm{~nm}$ is measured. In the presence of hydroperoxide, GPx catalyses oxidation of GSH to GSSG. The latter (GSSG) undergoes NADPH-dependent reduction to GSH catalysed by glutathione reductase. This reaction is accompanied by NADPH oxidation to NADP+. Thus, activity of GPx corresponds to the decrease in absorbance at $340 \mathrm{~nm}$ induced by NADPH oxidation and one unit of enzyme activity is defined as the enzyme content required for oxidation of $1.0 \mu \mathrm{mol}$ of NADPH per $1 \mathrm{~min}$ at $340 \mathrm{~nm}$ and $37^{\circ} \mathrm{C}$.

Malondialdehyde (MDA) level in plasma was measured as suggested by Gavrilov (Гаврилов и др., 1987): at low pH and elevated temperature, MDA readily participates in nucleophilic addition reaction with 2-thiobarbituric acid (TBA), generating a red 1:2 MDA: TBA adduct. The reaction products was extracted with butanol and estimated at $535 \mathrm{~nm}$ and $580 \mathrm{~nm}$ by spectrophotometry.

The determination of superoxide dismutase (SOD, EC 1.15.1.1) employed xantine and xantine oxidase to generate superoxide radicals that react with 2-(4-iodophenyl)-3-(4nitrophenol)-5-phenyltetrazolium chloride to form a red formazan dye (Woolliams et al., 1983). The SOD activity was then measured by the degree of inhibitation of this reaction.

Data were processed using SPSS 20.0. Statistical significance of mean values was evaluated by means of the Paired-Samples T-Test and one-Sample KolmogorovSmirnov test. Interrelationship between parameters was evaluated by the Wilcoxon correlation coefficient; differences were considered as statistically significant at $P<0.05$.

\section{RESULTS}

The main results before PSM (BL) and after (PL) the mission are represented in the Table 1.
T able 2

PTSD MORBIDITY BEFORE (BL) AND AFTER (PL) THE MISSION

\begin{tabular}{l|c|c|c|c|c}
\hline Group & Number, $\mathrm{n}$ & $\begin{array}{c}\text { Average } \\
\text { age, years }\end{array}$ & $\begin{array}{c}\text { Response } \\
\text { rate }\end{array}$ & $\begin{array}{c}\text { Prevalence } \\
\text { rate }\end{array}$ & $\begin{array}{c}\text { Incidence } \\
\text { rate }\end{array}$ \\
\hline BL gr. & 143 & 27.36 & 97.90 & 0.0357 & - \\
PL gr. & 37 & 26.20 & 91.89 & 0.0882 & 0.1765
\end{tabular}

PTSD, Posttraumatic Stress Disorder

Baseline PTSD Prevalence rate (PR) was 0.0357, which after PSM PTSD PR increased by $147.06 \%$ to 0.0882 units (Table 2).

Baseline MDA plasma level (MDA BL, see Fig. 1) was $2.5582 \mu \mathrm{M}$, which after PSM MDA level (MDA PL) increased by $24.36 \%$ till $3.1815 \mu \mathrm{M}$ (Fig.2).

Baseline GPx activity (GPx BL, see Fig. 3) was 8061.98 U/L, which after PSM GPx level (GPx PL) decreased by 9.35\% till 7308.31 U/L (Fig. 4).

Baseline SOD plasma activity (SOD BL, see Fig. 5) was 1449.20 U/gHB, which after PSM SOD (SOD PL) increased by $2.89 \%$ till $31491.03 \mathrm{U} / \mathrm{gHB}$ (Fig. 6).

Baseline PTSD symptom severity (PCL-M score, points, BL, see Fig. 7) total score was 22.90 PCL-M points, after PSM PCL-M score increased by $14.45 \%$ to 26.21 points (Fig. 8).

A negative correlation was found between MDA and GPx (Fig. 9).

\section{DISCUSSION}

Prevalence of oxidation processes accompanied by antioxidant defence system failure leads to the development of oxidative stress, which is one of the universal mechanisms of tissue damage. Enzymatic activity of antioxidant systems (catalase, SOD, glutathione peroxidase) in the brain is sig- 


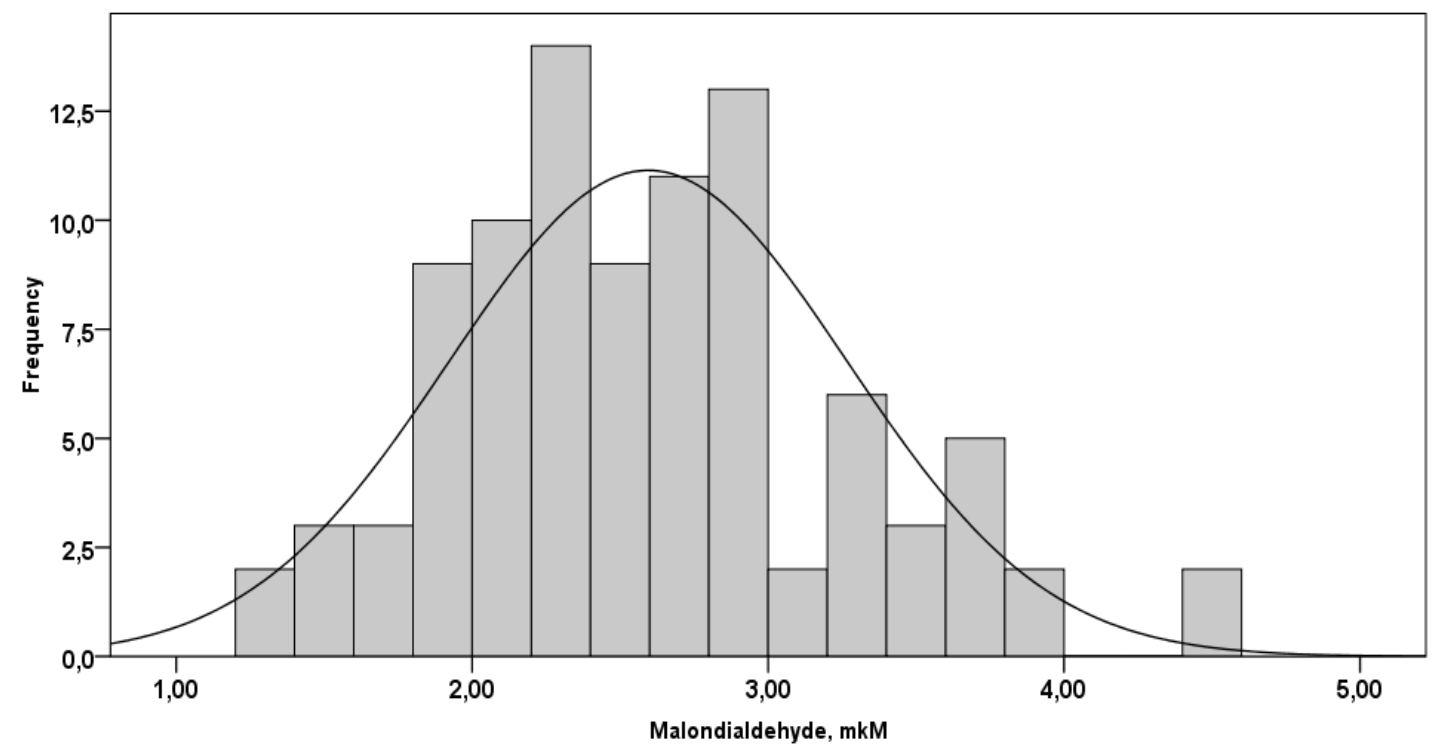

Fig. 1. Malondialdehide level distribution before the mission (BL).

nificantly lower than in other tissues. Oxygen radicals (having oxygen with an unpaired electron) are superoxide anion and hydroxyl radical. These are extremely aggressive. Glutamate is a substrate that is able to support maximal $\mathrm{H}_{2} \mathrm{O}_{2}$ production rates by means of $\left[\mathrm{Ca}^{2+}\right]$ mediated excitotoxity. Scavengers of free radicals are located in the cytoplasm or on cell membranes; these are mainly substances with low molecular weight: superoxide dismutase, glutathione, glutathione peroxidase, catalase, ceruloplasmin, vitamin A, vitamin E, vitamin $\mathrm{C}$, vitamin $\mathrm{K}$, flavonoids, and coumarins. Lipid peroxidation plays a crucial role in brain injury. The brain contains a large amount of lipids $(50 \%$ in a dry matter); most of them appear to be unsaturated and become substrates for lipid peroxidation. Phospholipids account for over half of all lipids of nervous tissue. Fatty acid and phospholipids determine structural and functional features of cell membranes, and contribute to its penetration and density. Lipid peroxidation of any intensity results in functional brain disorder (Esterbauer and Cheeseman, 1990; Ginsberg and Bogousslauvsky, 1998). Moreover, it could become a

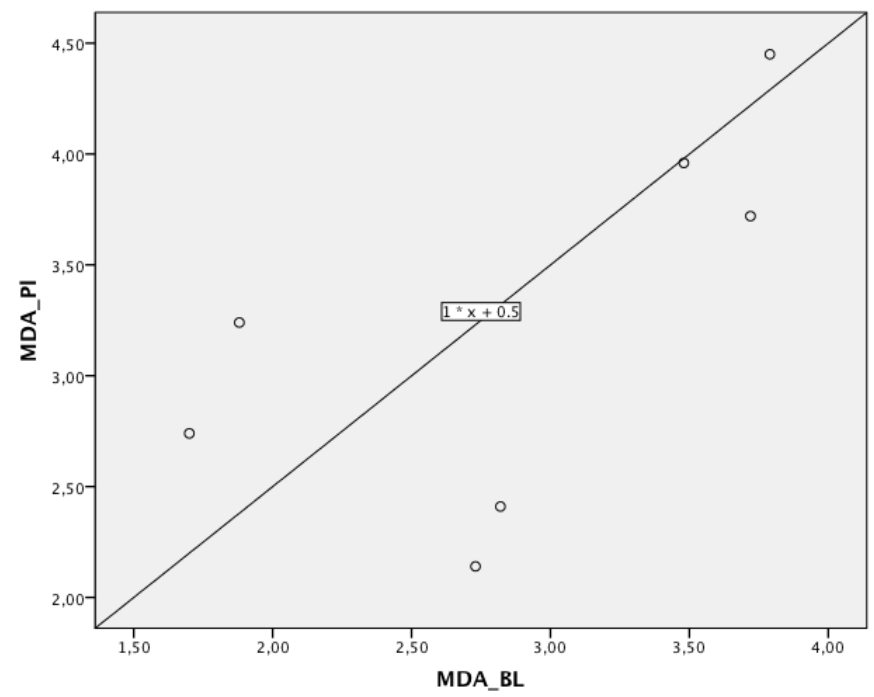

Fig. 2. Relationship of malondialdehide (MDA) before (BL) vs MDA after the mission (PL).

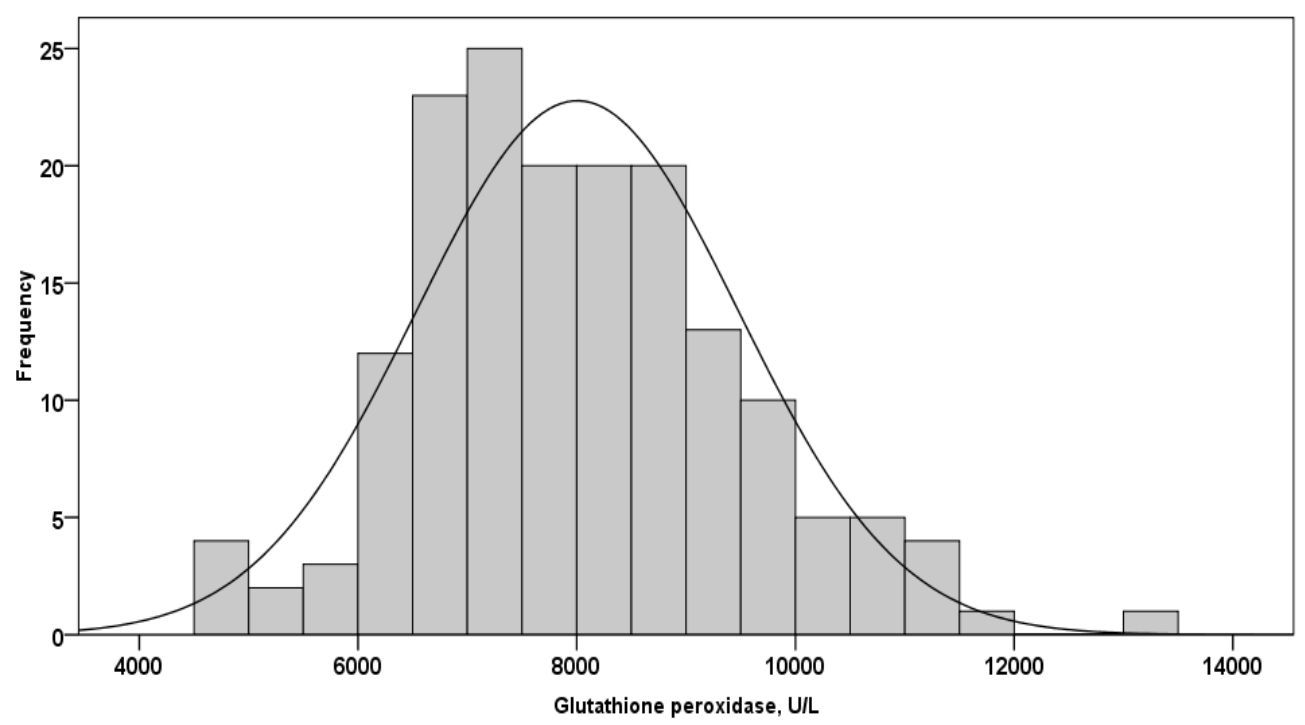

Fig. 3. Glutathione peroxidase level distribution before the mission. 
cause of structural and morphological alterations, and degeneration processes.

The PTSD patients note problems in cognition (memory, attention), somatic concerns (headache), and affective deregulation (impulsivity, irritability, anxiety), particularly in the time period shortly after the traumatic event (whether psychological, biomechanical, or both). A biochemical mechanism associated with elevated levels of oxidative stress parameters has been proposed to explain the etiology of PTSD (common etiology of posttraumatic stress disorder, fibromyalgia, chronic fatigue syndrome and multiple chemical sensitivity) (Pall, 2001; Pall and Satterlee, 2001; Pall, 2007; Adibhatla and Hatcher, 2008). Alterations of glutamatergic and NMDA receptor functions play a role in the etiology of PTSD in humans. Some clinical studies have observed a marked increase of cerebral neurotransmitter glutamate in PTSD (Moghaddam et al., 1994; Chambers et al., 1999; Cortese and Phan, 2005). Stress increases glutamate release,

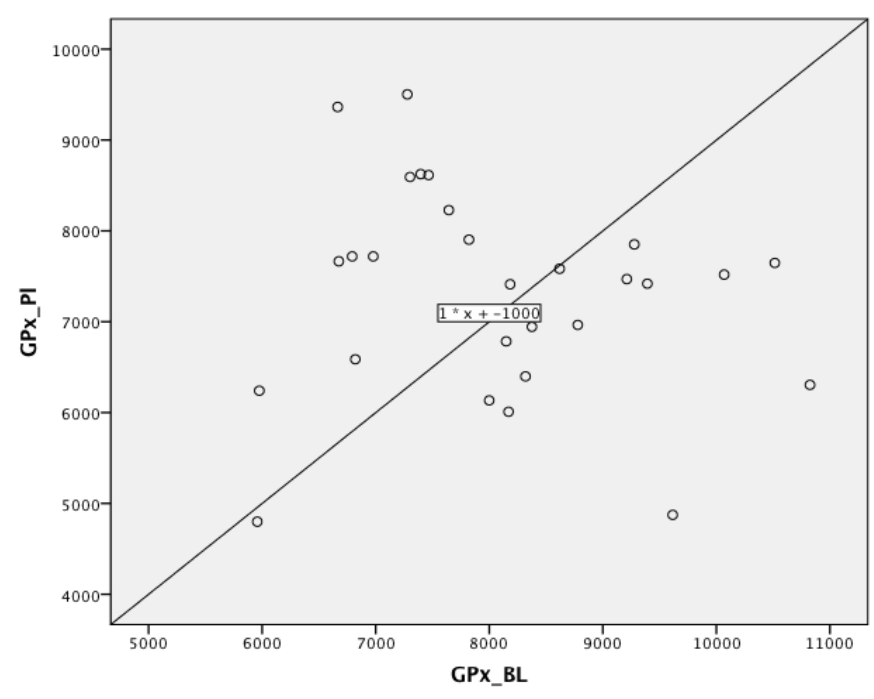

Fig. 4. Glutathione peroxidase before (BL) vs after the mission (PL).

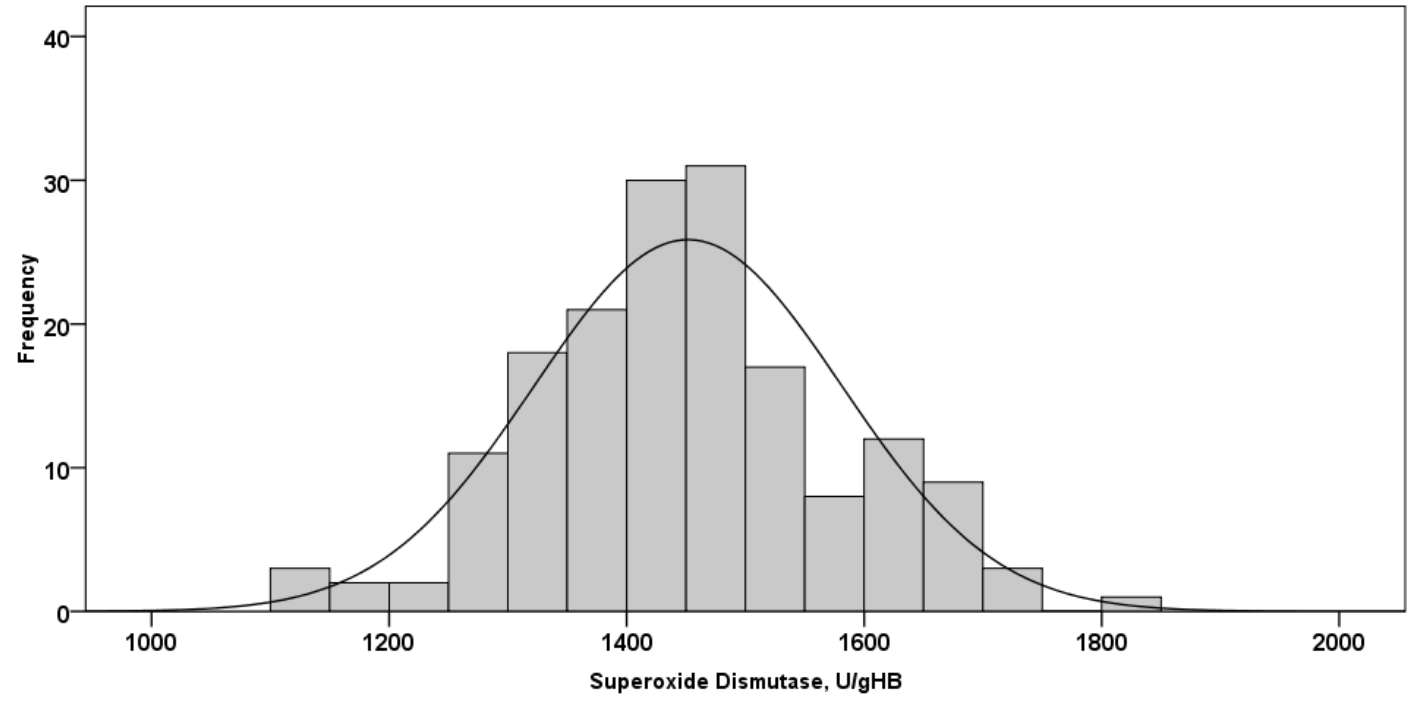

Fig. 5. Superoxide dismutase level distribution before the mission. which is recognised as an important mediator of excitotoxity. Since a prominent role of glutamate-related excitotoxity followed by neuronal damage, glutamatergic pathways may have an important role in stress-related hippocampal degenerative pathology and cognitive deficits seen in patients with PTSD (Moghaddam et al., 1994). Brain imaging studies have revealed a marked reduction in hippocampal volume (Sapolsky, 2000; Reul and Nutt, 2008). Such morphological alterations appear to be positively correlated with the degree of cognitive deficit noted in these patients. PTSD-induced oxidative stress has been proposed to occur in this disorder. Recent clinical studies confirmed the involvement of neurodegenerative pathology in the PTSD pathogenesis (Bremner, 2002). Neurochemically-mediated damage could be conceivably related to neurohumoral dysregulation.

The main conclusions are:

1. MDA intensity increased during PSM; MDA intensity reflects the rate of lipid peroxidation and OS severity.

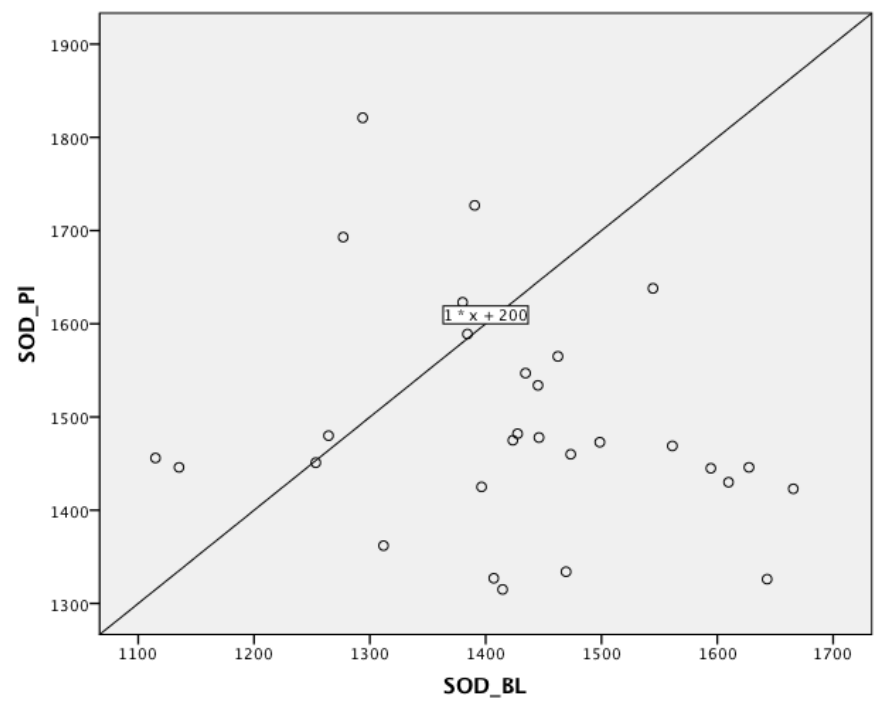

Fig. 6. Superoxide dismutase (SOD) before (BL) vs after the mission (PL). 


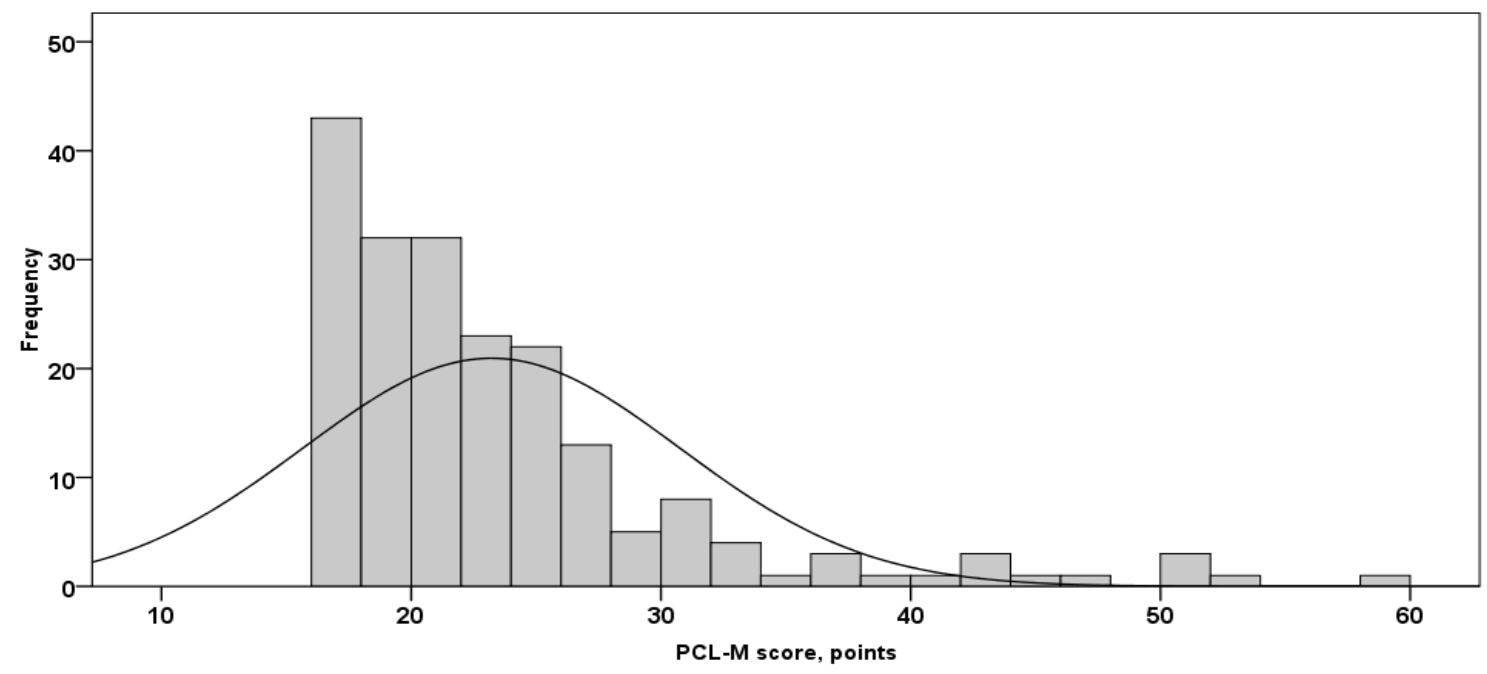

Fig. 7. PCL-M scores distribution, points, before the mission.

PCL-M, Posttraumatic Stress Disorder Checklist - Military Version

2. GPX activity is decreased in the PTSD risk group and is not efficient to overwork and/or control OS.

3. SOD activity is increased in the PTSD risk group but is not efficient to overwork and/or control OS.

4. There is positive correlation between increase of oxidative stress - MDA level, PTSD symptom severity level, and PTSD Prevalence rate (PR) in the studied group of patients with risk of PTSD (Contingent of the International Operations). PTSD PR depends on MDA intensity and OS severity.

Our results suggest that the production of free radicals resulteing in lipid peroxidation seemed to be related to PTSD. The present results showed that patients with PTSD differed from healthy controls in both antioxidant system activity (GPx, SOD) and lipid peroxidation (MDA) level. Therefore, we conclude that OS, increased free radical level beyond excitotoxity, is a possible causal factor for clinical manifes-

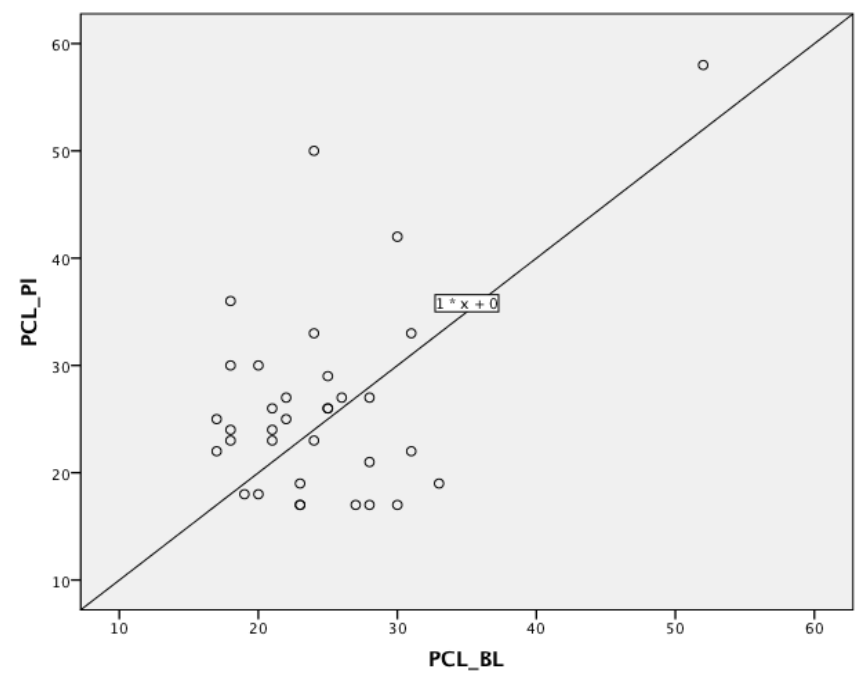

Fig. 8. PCL-M score before (BL) vs after the mission (PL).

PCL-M, Posttraumatic Stress Disorder Checklist - Military Version

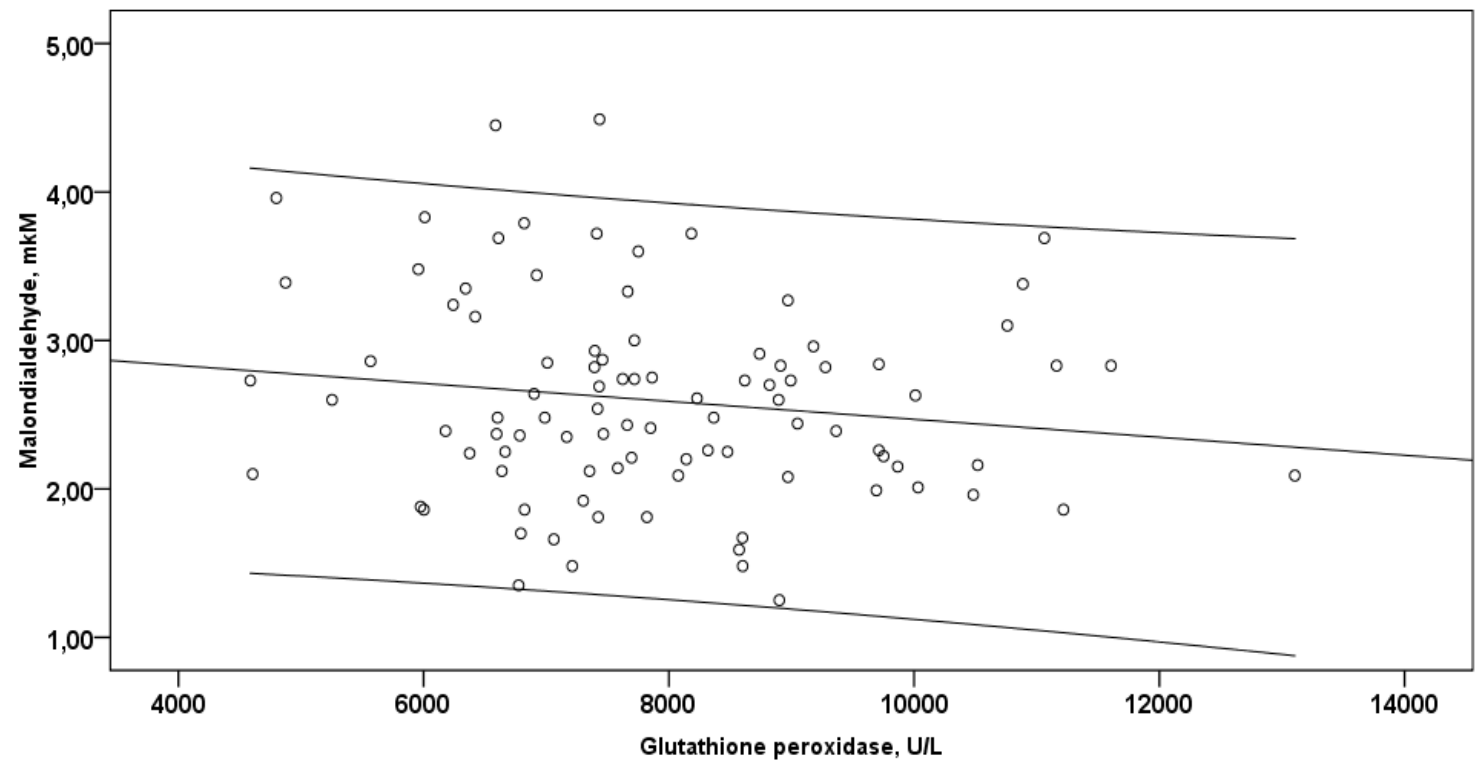

Fig. 9. Negative correlation between MDA and GPx.

MDA, malondialdehyde; GPx, glutathione peroxidase 
tation of PTSD. Our results need to be confirmed by more comprehensive and detailed further studies to support the findings we found in PTSD.

\section{ACKNOWLEDGEMENTS}

The research is supported by European Social Foundation co-financing: Project for Doctoral students support, at Rīga Stradiňs University (No. 2009/0147/1DP/1.1.2.1.2/09/IPIA/ VIAA/009). The views expressed in this article are those of the authors and do not reflect the official policy or position of the Latvian government, Latvian National Armed Forces, Medical Support Centre of Latvian National Armed Forces or any of the institutions with which the authors are affiliated. The authors state no conflict of interest. All authors read and approved the final manuscript.

\section{REFERENCES}

Adibhatla, R. M., Hatcher, J. F. (2008). Altered lipid metabolism in brain injury and disorders. Subcell. Biochem., 49, 241-68.

Anonymous (2000). Diagnostic and Statistical Manual of Mental Disorders (Revised 4th edn.). American Psychiatric Association. Washington, D.C. $\$ 309.81$.

Anwyl, R. (1991). Modulation of vertebrate neuronal calcium channels by transmitters. Brain Res. Brain Res. Rev., 16 (3), 265-281.

Bremner, J. D. (2002). Neuroimaging studies in post-traumatic stress disorder. Curr. Psychiatry Rep., 4 (4), 254-263.

Chambers, R. A., Bremner, J. D., Moghaddam, B., Southwick, S. M., Charney, D. S., Krystal, J. H. (1999). Glutamate and post-traumatic stress disorder: Towards a psychobiology of dissociation. Semin. Clin. Neuropsychiatry, 4 (4), 274-281.

Cortese, B. M., Phan, K. L. (2005). The role of glutamate in anxiety and related disorders. CNS Spectr., 10 (10), 820-830.

Del Rio, D., Stewart, A. J., Pellegrini, N. (2005). A review of recent studies on malonaldehyde as toxic molecule and biological marker of oxidative stress. Nutr. Metab. Cardiovasc. Dis., 15 (4), 316-328.

Esterbauer, H., Cheeseman, R. H. (1990). Determination of aldehydic lipid peroxidation products: Malonaldehyde and 4-hydroxynonenal. Methods Enzymol., 186, 407-421.

Ginsberg, M. D., Bogousslauvsky, J. (eds.) (1998). Cerebrovascular Disease: Pathophysiology, Diagnosis and Management. Malden: Blackwell Science. $2185 \mathrm{pp}$.

Hoge, C. W., Castro, C. A., Messer, S. C., McGurk, D., Cotting, D. I., Koffman, R. L. (2004). Combat duty in Iraq and Afghanistan, mental health problems, and barriers to care. New Engl. J. Med., 351 (1), 13-22.

Hotopf, M., Hull, L., Fear, N. T., Browne, T., Horn, O., Iversen, A., Jones, M., Murphy, D., Bland, D., Earnshaw, M., Greenberg, N., Hughes, J. H., Tate, A. R., Dandeker, C., Rona, R., Wessely, S. (2006). The health of UK military personnel who deployed to the 2003 Iraq war: A cohort study. Lancet, 367 (9524), 1731-1741.

Iversen, A. C., van Staden, L., Hughes, J. H., Browne, T., Hull, L., Hall, J., Greenberg, N., Rona, R. J., Hotopf, M., Wessely, S., Fear, N. T. (2009). The prevalence of common mental disorders and PTSD in the UK military: Using data from a clinical interview-based study. BMC Psychiatry, 9, 68.

Jourdain, P., Bergersen, L. H., Bhaukaurally, K., Bezzi, P., Santello, M., Domercq, M., Matute, C., Tonello, F., Gundersen, V., Volterra, A. (2007). Glutamate exocytosis from astrocytes controls synaptic strength. Nat. Neurosci., 10 (3), 331-339.
Moghaddam, B., Bolinao, M. L., Stein-Behrens, B., Sapolsky, R. (1994). Glucocortcoids mediate the stress-induced extracellular accumulation of glutamate. Brain Res., 655 (1-2), 251-254.

Li, Q. Y., Pedersen, C., Day, B. J., Patel, M. (2001). Dependence of excitotoxic neurodegeneration on mitochondrial aconitase inactivation. $J$. Neurochem., 78 (4), 746-755.

McDonald, S. D., Calhoun, P. S. (2010) The diagnostic accuracy of the PTSD Checklist: A critical review. Clin. Psychol. Rev., 30 (8), 976-987.

Milani, P., Gagliardi, S., Cova, E., Cereda, C. (2011). SOD1 Transcriptional and Posttranscriptional Regulation and Its Potential Implications in ALS. Neurol. Res. Int. Doi: 10.1155/2011/458427.

http://www.ncbi.nlm.nih.gov/pmc/articles/PMC3096450/

Miyamoto, Y., Koh, Y. H., Park, Y. S., Fujiwara, N., Sakiyama, H., Misonou, Y., Ookawara, T., Suzuki, K., Honke, K., Taniguchi, N. (2003). Oxidative stress caused by inactivation of glutathione peroxidase and adaptive responses. Biol. Chem., 384 (4), 567-574.

Moore, K., Roberts, L. J.2nd. (1998). Measurement of lipid peroxidation. Free Radic. Res., 28 (6), 659-671.

Nie, C. L., Wang, X. S., Liu, Y., Perrett, S., He, R. Q. (2007). Amyloid-like aggregates of neuronal tau induced by formaldehyde promote apoptosis of neuronal cells. BMC Neurosci., 8, 9.

Paglia, D. E., Valentine, W. N. (1967). Studies on the quantitative and qualitative characterization of erythrocyte glutathione peroxidase. J. Lab. Clin. Med., 70 (1), 158-169.

Pall, M. L. (2001). Common etiology of posttraumatic stress disorder, fibromyalgia, chronic fatigue syndrome and multiple chemical sensitivity via elevated nitric oxide/peroxynitrite. Med. Hypotheses, 57 (2), 139-145.

Pall, M. L. (2007). Explaining “Unexplained Illnesses": Disease Paradigm for Chronic Fatigue Syndrome, Multiple Chemical Sensitivity, Fibromyalgia, Post-Traumatic Stress Disorder, Gulf War Syndrome and Others. New York: Informa. 150 pp.

Pall, M. L., Satterlee, J. D. (2001). Elevated nitric oxide/peroxynitrite mechanism for the common etiology of multiple chemical sensitivity, chronic fatigue syndrome, and posttraumatic stress disorder. Ann. N. Y. Acad. Sci., 933, 323-329.

Pynoos, R. S., Steinberg, A. M., Layne, C. M., Briggs, E. C., Ostrowski, S. A., Fairbank, J. A. (2009). DSM-V PTSD diagnostic criteria for children and adolescents: A developmental perspective and recommendations. $J$. Trauma. Stress, 22 (5), 391-398.

Reul, J. M., Nutt, D. J. (2008). Glutamate and cortisol — a critical confluence in PTSD? J. Psychopharmacol., 22 (5), 469-472.

Riddle, J. R., Smith, T. C., Smith, B., Corbeil, T. E., Engel, C. C., Wells, T. S., Hoge, C. W., Adkins, J., Zamorski, M., Blazer, D. (2007). Millennium Cohort: The 2001-2003 baseline prevalence of mental disorders in the U.S. military. J. Clin. Epidemiol., 60 (2), 192-201.

Sapolsky, R. M. (2000). The possibility of neurotoxicity in the hippocampus in major depression: A primer on neuron death. Biol. Psychiatry, 48 (8), 755-765.

Satcher, D. (2000). Mental health: A report of the Surgeon General-Executive summary. Prof. Psychol.: Res. Practice, 31 (1), 5-13.

Trachootham, D., Lu, W., Ogasawara, M. A., Nilsa, R. D., Huang, P. (2008). Redox regulation of cell survival. Antioxid. Redox Signal,10 (8), 1343-1374.

Voicehovskis, V., Ancane, G., Voicehovska, J., Umnova, L., Skesters, A. (2011). Posttraumatic stress disorder checklist military version in Latvian language. Eur. Psychiatry, 26, 1088.

Watson, P., McFall, M., McBrine, C., Schnurr, P. P., Friedman, M. J., Keane, T., Hamblen, J. L. (2005). Best Practice Manual for Posttraumatic Stress Disorder (PTSD) Compensation and Pension Examinations. U.S. Dept of Veterans Affairs, Washington, D.C. 117 p. 
Weathers, F. W., Keane, T. M., Davidson, J. (2001). Clinician-administered PTSD scale: A review of the first ten years of research. Depress. Anxiety, 13 (3), 132-156.

Woolliams, J. A., Wiener, G., Anderson, P. H., McMurray, C. H. (1983). Variation in the activities of glutathione-peroxidase and superoxidedismutase and in the concentration of copper in the blood in various breed crosses of sheep. Res. Vet. Sci., 34 (3), 253-256.
Гаврилов В. Б., Гаврилова А. Р., Мажуль Л. М. (1987). Анализ методов определения продуктов перекисного окисления липидов в сыворотке крови по тесту с барбитуровой кислотой [Methods of determining lipid peroxidation products in the serum using a thiobarbituric acid test]. Вопросы мед. хим., 33 (1), 118-122.

Received 7 May 2012

\section{OKSIDATĪVĀ STRESA PARAMETRI POSTTRAUMATISKĀ STRESA SINDROMA RISKA GRUPAS PACIENTIEM}

Paaugstināts eksaitotoksicitātes līmenis kā atbildes reakcija uz stresoriem lieka reaktīvā skābekḷa/slāpekḷa uzkrāšanās rezultātā izraisa oksidatīvo stresu (OS). Neironālo membrānu fosfolipīdi ir īpaši jutīgi pret oksidatīvo bojājumu, rezultātā mainot signālu pārneses mehānismu. Starptautisko operāciju kontingents (SOK) tiek pakḷauts dažādiem ekstremāliem stresoriem, kas varētu izraisīt posttraumatiskā stresa sindromu (PTSS). Pieejamie pētījumu dati nav viendabīgi pēc dzimuma, rases, vecuma, uztura un dažādiem dienesta faktoriem un stresoriem, kas apgrūtina to salīdzināšanu. Pētījuma mērkis: novēertēt OS līmeni PTSS riska grupā. Pētījumā piedalījās 143 dalībnieki — Latvijas SOK, regulārais militārais personāls, vīrieši, eiropieši, kuru vidējais vecums ir 27,4 gadi, ar vienādiem uzdevumiem misijas laikā — tika izmeklēti divus mēnešus pirms un uzreiz pēc sešu mēnešu ilgas Miera uzturēšanas misijas (MUM) Afganistānā. PTSS novērtēšanai izmantota PCL-M anketa, apstiprināta latviešu valodas "militārā" versija. Asinīs noteikti OS rādītāji: glutationa peroksidāze (GPx), superoksīda dismutāze (SOD) un lipīdu peroksidāciju intensitātes rādītājs — malondialdehīds (MDA). Dati tika apstrādāti, izmantojot SPSS 20.0. MDA bāzes līmenis $(2,5582 \mu \mathrm{M})$ pēc MUM pieauga par 24,36\% (3,1815 $\mu \mathrm{M})$. GPx bāzes līmenis (8061,98 U/L) pēc MUM samazinājās par 9,35\% (7308,31 U/L). SOD bāzes līmenis (1449,20 U/gHB) pēc MUM palielinājās par 2,89\% (1491,03 U/gHB). PTSS simptomu smaguma (PCL-M punktu skaits) bāzes līmenis bija 22,90 punkti, pēc MUM tas palielinājās par 14,45\% (26,21 punkts). PTSS izplatības koeficienta (IK) bāzes līmenis bija 0,0357, pēc MUM tas pieauga par 147,06\% (0,0882). Autori secina, ka pastāv pozitīva korelācija starp OS pieaugumu, PTSS simptomu smaguma pakāpes līmeni un PTSS IK pacientiem PTSS riska grupā (SOK). PTSS IK ir atkarīgs no MDA līmeṇa un OS smaguma. Iespējams, ka OS un eksaitotoksicitātes rezultātā palielinātais brīvo radikāḷu līmenis ir veicinošs faktors PTSS klīniskās izpausmes attīstībai. 